\title{
BUDIDAYA TANAMAN MAHONI (Sweitenia macrophylla) DAN PEMANFAATANNYA SEBAGAI TANAMAN OBAT
}

\author{
Anak Agung Komang Suardana ${ }^{1}$
}

\begin{abstract}
Batukau Mount with its dense forest as the lungs of Tabanan Regency. As a buffer zone, water sources can irrigate existing subak, one of them is Jatiluwih Subak which is a World Cultural Heritage. At the south foothill of Mount Batukau Mount there is Sad Kahyangan Temple, Batukau Temple. Nature preservation around the temple is still maintained, but over time there are areas that need to be greened. Based on this situation, community service around Batukau Temple is carried out with the theme "Mahogany Cultivation (Sweitenia macrophylla) and Its Use as Medicinal Plants". The community service method was carried out with a lecture system to several community members in Batukau Temple. Conclusions obtained in the cultivation of mahogany plants that need to be considered are hatcheries and nurseries, planting and maintenance. As a medicinal plant, mahogany seed extract can be used as an environmentally friendly vegetable pesticide to control Plutella xylostella and Crosidolomia binolalis in cabbage when pests were in the larval stage and seeds of mahogany fruit contain various substances including flavonoids and saponins that function as bacteriocytes.
\end{abstract}

Key Word : cultivation, Mahogany plant, medicinal plants

\section{Pendahuluan}

Kabupaten Tabanan adalah salah satu kabupaten di Bali yang masih memiliki hutan cukup luas. Hutannya terjaga dan terpelihara dengan baik sehingga tetap rimbun dan lestari. Keberadaan Gunung Batukaru dengan vegetasi tumbuhan yang rimbun berdampak terhadap lingkungan sekitarnya. Gunung Batukaru masih asri, belum banyak terjamah oleh tangan-tangan jahil sehingga memberi kesan masih perawan atau bahkan bisa disebut sakral. Keberadaan tiga danau yaitu danau Beratan, Tamblingan dan danau Buyan sebagai penyuplai air sehingga kesuburan tanah terjaga dengan baik.

Selain hutan yang masih asri, Kabupaten Tabanan juga memiliki Pura Sad Kahyangan, salah satunya yaitu Pura Batukau atau sering disebut Pura Batu Karu.

${ }^{1}$ Dosen Fakultas Matematika dan Ilmu Pengetahuan Alam, Universitas Hindu Indonesia Denpasar, email. suardanaunhi@gmail.com 
Keberadaan Pura Batukau terletak di Desa Wongaya Gede, Kecamatan Penebel, Kabupaten Tabanan. Pura tersebut berada di tengah hutan dengan akses jalan beraspal. Upacara Wana Kerthi yaitu upacara keagamaan yang bermakna ucapan syukur terhadap sang pencipta terutama terhadap kelestarian hutan pernah dilaksanakan di kawasan Pura Batukau.

Untuk menunjang pelestarian hutan di kawasan Pura Batukau, salah satu kegiatan yang dilaksanakan adalah pengabdian dengan tema "Budi Daya Tanaman Mahoni (Sweitenia macrophylla) dan pemanfaatannya sebagai tanaman obat". Tanaman Mahoni dapat difungsikan sebagai penyangga tanah, penghasil kayu dan sebagai tanaman obat. Berdasarkan hal tersebut penulis mengadakan pengabdian di sekitar Pura Batukau dengan harapan masyarakat mengetahui cara budi daya tanaman Mahoni (Sweitenia macrophylla) dan pemanfaatanannya sebagai tanaman obat.

\section{Metode Pelaksanaan}

Bahan yang dipakai dalam pengabdian ini adalah bahan peraga berupa power point yang berisi penetahuan tentang budidaya tanaman mahoni serta manfaatnya sebagai bahan obat.

Saat pengabdian dilaksanakan mempergunakan teknik pengenalan tanaman Mahoni kepada prajuru Pura Batukau. Pengenalan mengenai teknik budidaya serta pemanfaatan Mahoni sebagai bahan obat.

\section{Hasil dan Pembahasan}

\section{A. BUDIDAYA TANAMAN MAHONI (Sweitenia macrophylla) \\ 1. PERBENIHAN DAN PEMBIBITAN}

Pemanenan buah : Buah sebaiknya dipetik langsung dari pohon sebelum buah merekah atau dapat juga benihnya dikumpulkan dari bawah tegakan sesaat setelah jaruh, Pada umumnya buah diunduh dengan cara memanjat pohon mahoni dan mengunduh benih yang telah masak fisiologis. Buah masak fisiologid dicirikan dengan buah berwarna coklat tua keabu-abuan dengan dengan bintik putih pada hampir separuh bagian kulit buat dan buahnya 
sudah mudah pecah. Di dalamnya benih bersayap warna coklat tua. Produksi benih bervariasi menurut tempat tumbuh dan umur. Pohon dewasa mahoni dapat menghasilkan sekirar lebih 200 buah masak pertahun atau sekitar 2,5- 4 $\mathrm{kg}$ benih. Jumlah benih per kg berkisar antara 1429-2500 benih dan jumlah benih per buah dapat mencapai 29-58 benih.

Ekstraksi benih : Ekstraksi benih dilakukan dengan cara kering yaitu buah diperam (after rifening) kemudian di jemur dibawah sinar matahari selama 1 - 4 hari hingga merekah atau bisa dilakukan pemecahan secara manual sampai benih keluar dari buah. Sayap benih dipotong sebagian tetapi tidak sampaui merusak struktur bagian dalam benih.

\section{Penyimpanan benih dan pengendalian hama}

penyakit benih : Sebelum dilakukan penyimpanan, kadar air benih harus diturunkan rerlebuh dahulu benih dijernur selama 1-2 hari lalu kering-anginkan selama 1 hari hingga kadar air rnencapai 5\%-8\%. Kernudian benih dapat disimpan dengan memasukkan ke dalam wadah kedap udara dan disirnpan di ruang ber AC suhu I $8^{\circ} \mathrm{C}-20^{\circ} \mathrm{C}$, kelembaban nisbi $70 \%$ atau disimpan di ruang DCS (dryc old storage) suhu $4^{\circ} \mathrm{C} 8^{\circ} \mathrm{C}$ dengan kelembaban nisbi $40 \%-50 \%$. Pengendalian hama dan penyakit benih saat penyimpanan dapat dilakukan dengan selalu mernpertahankan kadar air ama benih mahoni 5-8\%. Sedangkan jika timbul cendawanAspergillus sp., Botryodoplodia sp., Curvularia sp. dan Fusarium sp. pada benih, pengendaliannya dapat dilakukan dengan cara pemberian benomil $50 \%$ atau 25 gram dari berat total benih.

\section{Perkecambahan}

Sebelum benih ditanarn, sebaiknya media semainya disterilkan terlebih dahulu dengan cara disangrai atau diberi fungisida. Untuk mencegah serangan harna, bak kecambah dibuat setinggi \pm 1 meter dari permukaan tanah. Media semai dari campuran tanah dan pasir halus, dengan perbandingan $1: 1$ atau $2: 1$ yang diraruh pada bak kecambah.

Uk:uran bak kecambah $5 \times 1 \mathrm{~m}$ atau $2 \times 1 \mathrm{~m}$. Pekecambahan benih dilakukan dengan cara menabur benih dan membenamkannya dalam media 
sedalam 2/3 bagian dengan posisi sayap di atas.. Bak kecambah diberi naungan dari paranet $60 \%$. Untuk menjaga kelembaban pada bedeng tabur, dilakukan penyiraman dua kali atau saru kali dalam sehari. Benih akan mulai berkecambah pada hari ke 5 - 21. Benih yang memiliki rnutu yang baik dapat berkecambah sekitar 90-100\%. Benih yang sudah berkecambah selanjutnya disapih kedalam kantong plastik ukuran $8 \times 15 \mathrm{~cm}$.

Cara lain penaburan biji dapat dilakukan ke kontainer arau kantong plastic semai yang sudah diberi lobang- lobang kecil. Media yang digunakan adalah media yang sama dengan yang digunakan sama seperti pada bak kecambah. Pada cara ini tidak diperlukan penyapihan bib it, tetapi diperlukan penyulaman pada kantong plastik yang bijinya tidak tumbuh.

\section{Persemaian}

Persemaian dapat dibuat secara permanen untuk penyediaan bibit dalam jumlah banyak atau persemaian sementara untuk areal tanam terbatas. Benih disemai dengan cara membenamkannya sedalam $1 \mathrm{~cm}$ dalam bak kecambah yang telah berisi media semai dengan jarak sekitar S x $3 \mathrm{~cm}$ secara teratur. Penyapihan semai dari bak kecambah kedalam kancong bibit, hams dilakukan dengan hati-hati agar akar tidak patah atau rusak Semai ditanam secara berdiri cegak dan akar semai tidak melipat.

Penyapihan dilakukan pada pagi hari atau sore hari dan dilakukan dibawah naungan. Bibit yang telah disapih dipindahkan dan disusun pada bedeng sapih berukuran S X $1 \mathrm{~m}$ untuk dipelihara menjadi bibit sampai siap tanam. Pemupukan pertama dengan NPK dilakukan sewaktu mencampur media semai dengan dosis 1 gram (1 sendok teh) setiap kantong. Pemupukan kedua dan selanjumya dilakukan setiap bulan dengan dosis yang sama.

Bibit siap ditanarn di lapangan setelah berumur \pm 6 bulan. Ukuran tinggi bibit $\pm 25 \mathrm{~cm}$ (dari pangkal batang sampai ujung daun), bagian batang bibit sudah berkayu, diameter bibit > $2 \mathrm{~mm}$, sehat dan segar. Mahoni dapat ditanam dengan menggunakan stump (panjang $20-40 \mathrm{~cm}$ ) Pembuatan stump mahoni dilakukan di persemaian. menggunakan bibit mahoni yang sudah mencapai 
tinggi $\mathrm{SO} \mathrm{cm}$ dan berdiameter $1 \mathrm{~cm}$. dengan perbandingan 3 bagian akar dan I bagian batang.

\section{PENANAMAN}

\section{Penyiapan lahan}

Persiapan lahan untuk penanaman dilakukan dengan membersihkan semak belukar secara mekanis maupun manual tergantung kondisi lahan yang akan ditanami. Serangkaian kegiatan penyiapan lahan untuk lahan yang ada pohonnya rerdiri atas: penebasan, penebangan pohon• pohon pengganggu jika ada, Pencincangan sisa tebangan dan perapihan. Hasil pekerjaan penyiapan lahan adalah terbentuknya lahan rerbuka yang sudah bersih dari rerumputan, semak belukar serta pepohonan yang tidak diinginkan dengan serasah dan sisa tebangan yang tidak digunakan dapat dicincang jadi potongan-potongan kecil dan disebarkan secara merata. Potongan-potongan tersebut nantinya akan terdekomposisi dan menjadi masukan unsur hara atau pupuk untuk meningkatkan kesuburan. Sedangkan untuk lahan-lahan dengan kemiringannya relatif rerjal, penyiapan lahan dapat dilakukan dengan pembersihan secara jalur tanam selebar 1-2 meter tergantung kondisi vegetasi yang ada dan lahannya.

\section{Sistem penanaman}

Sistern penanaman mahoni dapat dilakukan secara monokultur yaitu murni tanaman mahoni dalam satu hamparan lahan, secara campuran antara tanaman mahoni dengan tanaman kehutanan lainnya ( sengon, jabon dan lainnya) atau dapatpula secara tumpangsariyang dicampur dengan tanaman pertanian (tanaman semusim, palawija, tanaman buah-buahan, tanaman obatobatan dan lain-lain) tergantung kondisi lahan. Untuk lahan terjal dan lahan yang tidak subur sebaiknya penanaman secaracampuran sedangkan untuk lahan yang relatifsubur, lahan rakyat atau lahan penyangga sebaiknya secara tumpangsari. Sistem tumpangsari yang sudah banyak dilakukan adalah tumpangsari mahoni dengan menanam tanaman palawija ( padi gogo, jagung, kacang, dll ). 


\section{Jarak Tanam}

Pengaturan jarak tanam ditentukan oleh kondisi lahan dan tujuan penanaman. Jikamenggunakan sistern monokultur atau campuran, jarak tanam yang digunakan adalah $3 \times 2 \mathrm{~m}, 3 \times 3 \mathrm{~m}$ atau $3 \times 4 \mathrm{rn}$, sedangkan jika menggunakan sistem tumpang sari, jarak tanamnyasebaiknya minimal adalah $6 \mathrm{x}$ $3 \mathrm{~m}$ atau $\mathrm{S} \times \mathrm{S}$ meter, tergantung jenis tanaman pertaniannya. Kegiatan penentuanjarak tanam di lapangan sebaiknya menggunakan kompas agar rapih. Lakukan penandaan jarak tanam dengan ajir yang dibuat dari bamboo atau bahan lainnya berukuran sekitar panjang $1 \mathrm{~m}$ dan lebart $2 \mathrm{~cm}$ sebagai tanda untuk membuat lubang tanam.

\section{Pembuatan lubang tanam}

Buat lubang tanam minimal berukuran 30 X 30 X $30 \mathrm{~cm}$ ditempat pemasangan ajir biasanya 1-2 minggu sebelum tanarn. Lakukan pemberian pupuk dasar yaitu pupuk organik atau pupuk kandang yang telah masak di dasar lubang tanam sebanyak $1 \mathrm{Kg}$ atau pupuk anorganik 50 gram perlubang tanam, kemudian cutup dengan tanah sebagian agar pupuk tersebut ridak langsung bersentuhan dengan akar tanaman saat awal penanaman.

\section{Pengangkutan bibit}

Menjelang waktu pelaksanaan penanaman, bibit harus sudah berada dekat dengan lahan yang akan di tanami agar bibit dapat beradaptasi dengan lingkungan tanam. Untuk lahan yang luas (HTI, HTR), biasanya ada kegiatan pemindahan bibit dari persemaian ke tempat penanaman, sebelum diangkut bibit disiram terlebih dahulu dan pengangkutan bibit sebaiknya dilakukan pagi atau sore hari. Kegiatan bongkar muat bibit harus dilakukan secara hati-hati jangan mengangkat bibit pada batangnya agar bibit utuh dengan medianya. Siram dan rawadah bibit minimal selama 2-3 hari sebelum ditanam. Sedangkan jika penanaman dilakukan berdekatan dengan tempat bib it berada atau penanaman di areal dekat pemukiman, bib it bisa langsung ditanam tan pa perlu waktu adaptasikarena kondisi lingkungan relatif sama.

\section{Penanaman}


Penanaman dilakukan pada awal musim hujan, yaitu setelah curah hujan cukup merata sekitar intensitas $100 \mathrm{~mm} / \mathrm{hari}$ atau tanah telah basah sampai kedalaman $30 \mathrm{~cm}$. Cara penanaman dapat dilakukan dengan terlebih dahtilu melepas kantong bibit dengan hati-hati dapar dilakukan dengan menyayat sebagian kantong atau merobeknya sehingga media tumbuh tetap utuh. Kemudian bibit ditanam pada lubang secara tegak lurus dan usahakan akar tidak terlipat, jika ada akar serabut yang keluar media dapat dipotong kecuali akar tunjang, Tutup lubang tanam dengan tanah bekas galian lubang sampai batas leher akar dan padatkan tanah atasnya agar menyangga bibit yang baru di tanam.

\section{PEMELIHARAAN}

\section{Penyulaman}

Penyulaman adalah mengganti tanaman yang mati, dapat dilakukan I - 2 bulan sesudah penanaman, yaitu sewakru curah hujan masih banyak dengan bibit yang sama umurnya Penyulaman berikumya serelah tan am an di lapangan berumur 1 - 2 rahun serta dilakukan pada musim penghujan.

\section{Penyiangan dan pendangiran}

Penyiangan clan pendangiran dilakukan minimal 3 kali setahun. Pada tahun pertama clan kedua lakukan penyiangan total agar tanarnan mahoni muda bebas dari gulma. Sedangkan pendangiran bertujuan rnernperbaiki kondisi fisik tanah disekitar tanaman mahoni dengan jalan menggemburkan tanah sekelilingtanaman mahoni muda dengan jarijari 0,5 s/d 1 meter.

\section{Pemupukan}

Pada areal yangkurangsubur, pemupukan akan memacu pertumbuhan anakan mahoni di lapangan. Lakukan pemupukan dengan pupuk anorganik majernuk NPK sebanyak 75 gram sampai 100 gram per pohon pada tahun pertama. Jika tidak menggunakan pupuk majernuk, dapat menggunakan pupuk anorganik lain dengan dosis sebesar 3,6 gram $\mathrm{N}+2,4$ gram P205 + 3,6 gram K10 perpohon atau dapat juga clengan dosis $100 \mathrm{~kg}$ Urea +50 kg Phospat $+50 \mathrm{~kg} \mathrm{KCL}$ per hektar. Fosfor merupakan faktor pembatas 
bagi pertumbuhan mahoni sehingga pernupukan sangat diperlukan. Di lahan hutan rakyat yang berdekatan dengan pernukiman, pernupukan dapat juga dilakukan dengan menambahkan pupuk kanclang yang telah masak atau dengan menumpukan mulsa daun kering di sekitar pohon.

\section{Pemberantasan hama dan penyakit}

Hama yang sering rnerusak tanaman mahoni adalah penggerek pucuk yaitu Hypsipyla robusta sehingga terjadi kernacian pucuk clan benruk batang jadi pendek dan banyak cabang. Pengendalian penggerek pucuk tersebut dapat dilakukan clengan menggunakan insektisida sisternik seperti Dimecron, Nuvacron dan Perfektion dengan dosis $2 \mathrm{sl}$ d 4 cc perliter air menjeang musim hujan setiap 10 hari sekali sampai 3 kali berturut-turut. Untuk mengurangi serangan hama clan penyakit, penanaman mahoni dapat dicampur dengan jenis Melia azedarachra dan Azadirachta indica secara selang seling. Selain itu perlunya pengecekan kesehatan tanaman scsering mungkin agar serangan hama clan penyakit terdereksi 1 bih awal sebelum eksplosif clan secara fisik pengendaliannya clengan membuang bagian tanarnan yang terserang hama atau penyakit dan menguburnya sebelum menyebar ke bagian lain.

\section{B. PEMANFAATAN TANAMAN MAHONI SEBAGAI TANAMAN OBAT}

Ekstrak biji mahoni dapat digunakan sebagai pestisida nabati yang ramah luingkungan untuk mengendalikan hama pada pertanaman kubis, yaitu Plutella xylostella dan Crocidolomia binolalis khususnya pada saat hama berada pada stadia larva.

\section{Penutup}

\section{Simpulan}

Simpulan yang diperoleh bahwa dalam budidaya tanaman mahoni yang perlu diperhatikan adalah pembenihan dan pembibitan, penanaman dan pemeliharaan. Ekstrak biji mahoni dapat dipergunakan sebagai pestisida nabati yang ramah lingkungan untuk mengendalikan hama Plutella xylostella dan Crosidolomia binolalis pada kubis saat hama berada pada stadia larva dan biji 
buah mahoni mengandung berbagai zat diantaranya flavonoid dan saponin yang berfungsi sebagai bakteriosit.

Saran

Disarankan kepada masyarakat disekitar kawasan Pura Batukau ikut menjaga kelestarian lingkungan dengan memelihara tanaman Mahoni karena mempunyai banyak manfaat sekaligus sebagai tanaman obat

\section{Daftar Pustaka}

Ir. H. M. Husni Hasan, CES,_2017. Budi Daya Mahoni. Lingkungan Hidup dan Kehutanan Provinsi Banten

Mindawati N dan Megawati. 2013. Manual Budidaya Mahoni (Swietenia macrophylla, King). Kementerian Kehutanan, Jakarta

Nursyamsi dan Suhartati. 2013. Pertumbuhan Tanaman Mahoni ((Swietenia macrophylla, King). Balai Kehutanan Makassar. 